Agriculture

Agriculture fields

\title{
Reversible changes in protein phosphorylation during germinal vesicle breakdown and pronuclear formation in bovine oocytes in vitro
}

\author{
Ri C. Chian \\ McGill University \\ Marc A. Sirard \\ University of Laval
}

\author{
Jin T. Chung \\ McGill University \\ Bruce R. Downey \\ McGill University
}

\author{
Koji Niwa \\ Okayama University \\ Seang L. Tan \\ McGill University
}

This paper is posted at eScholarship@OUDIR : Okayama University Digital Information Repository.

http://escholarship.lib.okayama-u.ac.jp/agriculture_general/5 


\title{
Reversible changes in protein phosphorylation during germinal vesicle breakdown and pronuclear formation in bovine oocytes in vitro
}

\author{
R.C. Chian ${ }^{1,2}$, J.T. Chung ${ }^{1}$, K. Niwa ${ }^{3}$, M.A. Sirard ${ }^{4}$, B.R. Downey ${ }^{2}$ and S.L. Tan ${ }^{1}$ \\ McGill University, Montreal, Canada; McGill University, Ste-Anne de Bellevue, Canada; Okayama University, Okayama, \\ Japan; and University of Laval, Quebec, Canada
}

Date submitted: 22.11.02. Date accepted: 27.01.03.

\section{Summary}

This study examined the event of protein phosphorylation in bovine oocytes during germinal vesicle breakdown (GVBD) and formation of pronuclei following fertilisation in vitro. Immature oocytes were obtained from abattoir materials and cultured in vitro. The oocytes were labelled with [ $\left.{ }^{32} \mathrm{P}\right]$ orthophosphate at $3 \mathrm{~h}$ intervals from 0 to $12 \mathrm{~h}$ following maturation in culture or from 3 to $18 \mathrm{~h}$ following insemination. One-dimensional gel electrophoresis indicated that levels of protein phosphorylation are low prior to GVBD. However, the levels of protein phosphorylation at approximately $40 \mathrm{kDa}, 27 \mathrm{kDa}, 23$ $\mathrm{kDa}$ and $18 \mathrm{kDa}$ increased substantially following GVBD and then decreased gradually as maturation in culture progressed. In contrast, the levels of protein phosphorylation increased gradually in the oocytes following pronucleus formation. Further, two-dimensional gel electrophoresis indicated that the protein at approximately $18 \mathrm{kDa}$ reversibly changed in the oocytes during maturation and fertilisation. These results indicate that the reversible changes of this phosphoprotein may be related to either cell cycle transition or pronucleus formation during maturation and fertilisation in bovine oocytes.

Keywords: GVBD, Maturation, Oocyte, Pronucleus, Protein phosphorylation

\section{Introduction}

The reversible phosphorylation of proteins is now recognised to be a major mechanism for the control of intracellular events in eukaryotic cells. The relative concentration of phosphorylated and non-phosphorylated forms of protein substrates is controlled by two enzymes: a protein kinase and a protein phosphatase. Target proteins are phosphorylated at specific sites by one or more protein kinases, and these phosphates are

All correspondence to: R.C. Chian, PhD, Women's Pavilion F3-46, Royal Victoria Hospital, 687 Pine Avenue West, Montreal, Quebec, Canada H3A 1A1. Fax: +1 (514) 8431662. e-mail: ri-cheng.chian@muhc.mcgill.ca

${ }^{1}$ Department of Obstetrics and Gynecology, McGill University, Montreal, Canada H3A 1A1.

${ }^{2}$ Department of Animal Science, Macdonald Campus, McGill University, Ste-Anne de Bellevue, Canada H9X 3V9.

${ }^{3}$ Division of Animal Science and Technology, Faculty of Agriculture, Okayama University, 700-8530 Okayama, Japan. ${ }^{4}$ Department of Animal Science, University of Laval, Quebec, Canada G1K 7P4. removed by specific protein phosphatases. The importance of protein kinases in regulating cellular activities is underscored by the large number of protein kinase genes that are present in eukaryotic genomes (Hunter, 1995). There are also a large number of protein phosphatase genes, about half of which encode protein serine/threonine phosphatases and the other half protein tyrosine phosphatases (Wilson et al., 1994).

Obviously, protein phosphorylation and dephosphorylation play key roles in the regulation of meiotic maturation. The maturation-promoting factor (MPF) complex is a protein dimer composed of catalytic p3 $4^{c d c 2}$ serine/threonine kinase which is the homologue of the yeast cdc2/CDC28 protein kinase, and regulatory cyclin $B$ subunits which are the homologue of the yeast cdc 13 gene product (Maller et al., 1977; Gautier et al., 1990; Nurse, 1990). Activation of MPF requires key side phosphorylation and dephosphorylation. The product of the c-mos proto-oncogene, a protein serine/threonine kinase known as Mos (Sagata et al., 1989; Pines \& Hunter, 1990), and mitogen-activated protein kinase (MAP-kinase) (Watanabe et al., 1989), directly or indirectly modify MPF activity with the 
status of phosphorylation or dephosphorylation. Therefore, the phosphorylation cascade of Mos and MAP-kinase may play an important role in the meiotic and mitotic cell cycle from G2 to M-phase (Nebreda \& Hunter, 1993; Dekel, 1996).

Oocytes and sperm contain histone variants, which serve the unique physiological requirements of oogenesis, spermatogenesis and early embryogenesis. Phosphorylation sites are typically located within variant DNA-binding regions of sperm and oocyte histones, indicating that their special functions are realised through the charge-altering effects of reversible histone phosphorylation (Norbury \& Nurse, 1992). These indicate that histone kinases and phosphatases participate in the control of chromatin structure by altering histone-DNA interactions (Green \& Piccia, 1985, 1989). Upon entering the oocyte cytoplasm at fertilisation, the sperm nucleus undergoes a dramatic morphological transformation as the male pronucleus is formed. The sperm nucleus is transformed into the male pronucleus through the interaction of oocyte cytoplasmic components with sperm chromatin (Perreault et al., 1984; Green et al., 1995). Molecular analysis indicates that the first step in the processing of the sperm nucleus is reduction in protamine disulfide bonds (Longo \& Kunkle, 1978; Zirkin et al., 1985). The sperm-specific protamines are replaced by histone and non-histone proteins during pronuclear formation. Events related to pronuclear formation and subsequent DNA synthesis by the pronucleus appears to be related to the meiotic cycle of the oocytes. It has been suggested that several nuclear factors, which are necessary for inducing cytoplasmic changes and male pronucleus development following penetration of the oocyte, may be released during germinal vesicle breakdown (GVBD) of oocytes (Yanagimachi, 1978). The sperm pronucleus development factor (SPDF) may be synthesised as oocytes move from GVBD to metaphaseII (Thibault, 1977). Male pronucleus formation, however, is clearly dependent not only upon GVBD but also upon oocyte activation (Zirkin et al., 1985).

Inhibition of protein synthesis affects histone $\mathrm{H} 1$ kinase, but not chromosome condensation activity during the first meiotic division of the oocyte (Balakier \& Tarkowski, 1980). It seems clear that protein synthesis is not required for the transition from metaphase II to the female pronucleus (Zhang \& Masui, 1992; Moses \& Masui, 1994; Moses \& Kline, 1995; Kubelka et al., 1995; Hagemann et al., 1995). Inhibition of protein synthesis following sperm penetration shows that formation of the male pronucleus is not affected, suggesting that the newly synthesised proteins following fertilisation are not essential for male pronuclear formation (Chian \& Sirard, 1996). In some species, it has been suggested that protein phosphorylation and dephosphorylation are involved during male pronuclear formation (Howlett \& Bolton, 1985; Howlett, 1986; Reyes et al., 1991; Ding et al., 1992; Jung et al., 1993). The decondensation of sea urchin sperm chromatin following fertilisation is accompanied by specific protein phosphorylation (Poccia \& Collas, 1997). It has been demonstrated that protein phosphorylation is essential for formation of the male pronucleus in bovine oocytes (Chian et al., 1999a). Although the formation of the female pronucleus is not affected by 6-dimethylaminopurine (6-DMAP), which is a protein kinase inhibitor, male pronucleus formation is completely inhibited by the presence of 6-DMAP. These results also suggest that formation of male and female pronuclei may involve different factors in the bovine zygote since they respond differently to the kinase modulations. The phosphorylation of protein complexes of $23 \mathrm{kDa}$ and $18 \mathrm{kDa}$ specifically increased with the formation of male and female pronuclei, suggesting that these phosphoproteins are related to formation of the male pronucleus in bovine oocytes (Chian et al., 1999b). However, it is unclear how these specific phosphoproteins change during oocyte maturation and fertilisation.

If there were specific reversible phosphoproteins during oocyte maturation and fertilisation, these specific phosphoproteins may be involved not only in the cell cycle transition of G2/M but also in male pronucleus formation. To clarify protein phosphorylation in oocytes following maturation and fertilisation will be useful for understanding mechanisms of cell cycle transition and reprogramming of the sperm genome in oocytes. The objective of the present study was to examine the profile of protein phosphorylation during oocyte maturation and fertilisation in vitro in order to determine which protein(s) are related to the transition of $\mathrm{G} 2 / \mathrm{M}$ and formation of pronuclei following fertilisation.

\section{Materials and methods}

\section{Maturation of oocytes in vitro}

Ovaries from cycling or pregnant heifers or cows were removed within $30 \mathrm{~min}$ of slaughter and transported to the laboratory at $35^{\circ} \mathrm{C}$ in $0.9 \% \mathrm{NaCl}$ solution. Cumulus-oocyte complexes (COCs) were aspirated from 2-8 $\mathrm{mm}$ follicles with an $18 \mathrm{G}$ needle attached to a $10 \mathrm{ml}$ syringe, pooled and selected as described previously (Chian et al., 1994). The COCs were rapidly washed four times in HEPES buffered Tyrode's medium (TLH) (Bavister et al., 1983) supplemented with $10 \%$ heated $\left(56{ }^{\circ} \mathrm{C}\right.$ for $30 \mathrm{~min}$ ) fetal bovine serum (FBS), $0.25 \mathrm{mM}$ pyruvic acid and $50 \mu \mathrm{g} / \mathrm{ml}$ gentamicin. After washing, 10 COCs were cultured in $50 \mu \mathrm{l}$ droplets of maturation medium (TC-199 medium 
supplemented with $10 \%$ FBS, $0.75 \mathrm{mIU} / \mathrm{ml} \mathrm{FSH}$ and LH: Humegon, Organon Canada) under mineral oil. The COCs were cultured at $38.5^{\circ} \mathrm{C}$ under an atmosphere of $5 \% \mathrm{CO}_{2}$ in air with high humidity. To examine the process of GVBD, the oocytes were fixed at $1 \mathrm{~h}$ intervals from 0 to $12 \mathrm{~h}$ following maturation in culture.

\section{Sperm preparation and in vitro fertilisation}

Frozen semen, pooled from five bulls, was donated by Alliance Boviteq (L'Alliance Boviteq, St-Hyacinthe, Quebec) and GENCOR (Guelph, Ontario). Straws of semen were thawed in a water bath $\left(35^{\circ} \mathrm{C}\right)$ for $30 \mathrm{~s}$ and processed by swim-up as described by Parrish et al. (1986). The sperm were then washed twice with modified Tyrode's albumin lactate pyruvate medium (SpTALP) used for sperm culture containing $6 \mathrm{mg} / \mathrm{ml}$ fatty acid-free bovine serum albumin (BSA; Sigma), 10 $\mathrm{mM}$ pyruvic acid and $50 \mu \mathrm{g} / \mathrm{ml}$ gentamicin.

After $24 \mathrm{~h}$ of maturation, the COCs were washed twice with fertilisation medium (modified Tyrode's medium: mTALP), and then five COCs were transferred into $50 \mu \mathrm{l}$ drops of the fertilisation medium containing $2 \mu \mathrm{g} / \mathrm{ml}$ heparin (Sigma) under mineral oil at $38.5^{\circ} \mathrm{C}$ in $5 \% \mathrm{CO}_{2}$ in air with high humidity (Parrish et al., 1988). A final sperm concentration of $1 \times 10^{6}$ sperm $/ \mathrm{ml}$ was used for insemination. To examine the time course of formation of male and female pronuclei, the oocytes were fixed at $1 \mathrm{~h}$ intervals from 3 to $18 \mathrm{~h}$ following insemination.

\section{Fixation of oocytes}

At the end of each culture period, the oocytes were fixed as described previously (Chian \& Sirard, 1996). Briefly, the oocytes were mounted on slides with coverslips and then fixed with acetic acid/ethanol (1:3) solution for at least $24 \mathrm{~h}$. Following fixation, the oocytes were stained with $1 \%$ orcein in $45 \%$ acetic acid and examined for evidence of oocyte GVBD and sperm nuclear change under a phase-contrast microscope.

\section{Radiolabelling of oocytes}

To determine the pattern of protein phosphorylation during maturation and fertilisation, the oocytes were transferred into $50 \mu \mathrm{l}$ of mTALP+polyvinylpyrrolidone (PVP-40; Sigma) containing $400 \mu \mathrm{Ci} / \mathrm{ml}$ [32P]orthophosphate (Amersham, Arlington Heights, IL, USA) at $0,3,6$ and $9 \mathrm{~h}$ following culture and at 3 , $6,9,12$ and $15 \mathrm{~h}$ following insemination labelled for 3 $h$, respectively. The oocytes were then washed twice with TLH containing 0.3\% PVP and lysed with $60 \mu \mathrm{l}$ sodium dodecyl sulfate (SDS) buffer. The samples were precipitated with acetone (99\%), dried, and resuspended in $20 \mu \mathrm{l}$ SDS-buffer, and then frozen at $-80{ }^{\circ} \mathrm{C}$ until further use.

\section{Electrophoresis and autoradiography}

One-dimensional SDS polyacrylamide gel electrophoresis (SDS-PAGE) was performed with a 5\% stacking gel and a $12 \%$ separating gel according to the method of Laemmli (1970). For the two-dimensional gels, the first-dimension gel was performed in acryl gel with Nonidet P40 and urea. The second dimension was performed on $12 \%$ SDS-PAGE. Twenty-five oocytes were put into each well for electrophoresis. All gels were soaked for $30 \mathrm{~min}$ in fixation solution of $5 \%$ glycerol $/ 25 \%$ isopropanol $/ 10 \%$ acetic acid, and then dried under vacuum at $80^{\circ} \mathrm{C}$. Autoradiography was carried out at $-80^{\circ} \mathrm{C}$ with intensifying screens.

\section{Results}

A time course of oocyte GVBD is shown in Fig. 1. All oocytes just after aspiration from follicles were at the germinal vesicle $(\mathrm{GV})$ stage. A clear nucleolus was observed within the GV in some oocytes (Fig. 2a; $12 \%=8 / 65)$. However, the nucleolus disappeared after $1 \mathrm{~h}$ of culture (Fig. 2b), and dispersed chromosomes gradually began to gather with further culture (Fig. 2c, d). GVBD was first observed $3 \mathrm{~h}$ after maturation in culture (Fig. 2e) and condensation of chromosomes (condensed GV) proceeded with further culture (Fig. $2 f)$. All oocytes underwent GVBD after $10 \mathrm{~h}$ in culture.

A time course of the development of male and female pronuclei following insemination is shown in Fig. 3. The first evidence of formation of male and female pronuclei was observed $9 \mathrm{~h}$ after insemination and observed concurrently from 10 to $18 \mathrm{~h}$ postinsemination (Fig. 4).

The changes in protein phosphorylation in the oocytes occurred following maturation (Fig. 5a) and fertilisation (Fig. 5b). There were low levels of protein phosphorylation in the oocytes at the beginning of maturation (Fig. $5 a$, lane 1). However, overall protein phosphorylation increased following 3-6 h of culture (Fig. $5 a$, lane 2), and then the levels of protein phosphorylation at approximately $40 \mathrm{kDa}, 27 \mathrm{kDa}, 23 \mathrm{kDa}$ and $18 \mathrm{kDa}$ decreased gradually from 3 to $12 \mathrm{~h}$ following oocyte maturation in culture (Fig. 5a, lanes 2-4). Following fertilisation, the levels of phosphorylated protein at approximately $40 \mathrm{kDa}, 27 \mathrm{kDa}, 23 \mathrm{kDa}$ and $18 \mathrm{kDa}$ increased gradually from 6 to $18 \mathrm{~h}$ post-insemination (Fig. 5b, lanes 2-5).

Fig. 6 shows a two-dimensional profile of protein phosphorylation in the oocytes during GVBD. Referring to Fig. $5 a$, the points of phosphorylated protein at approximately $27 \mathrm{kDa}$ and $18 \mathrm{kDa}$ decreased following 


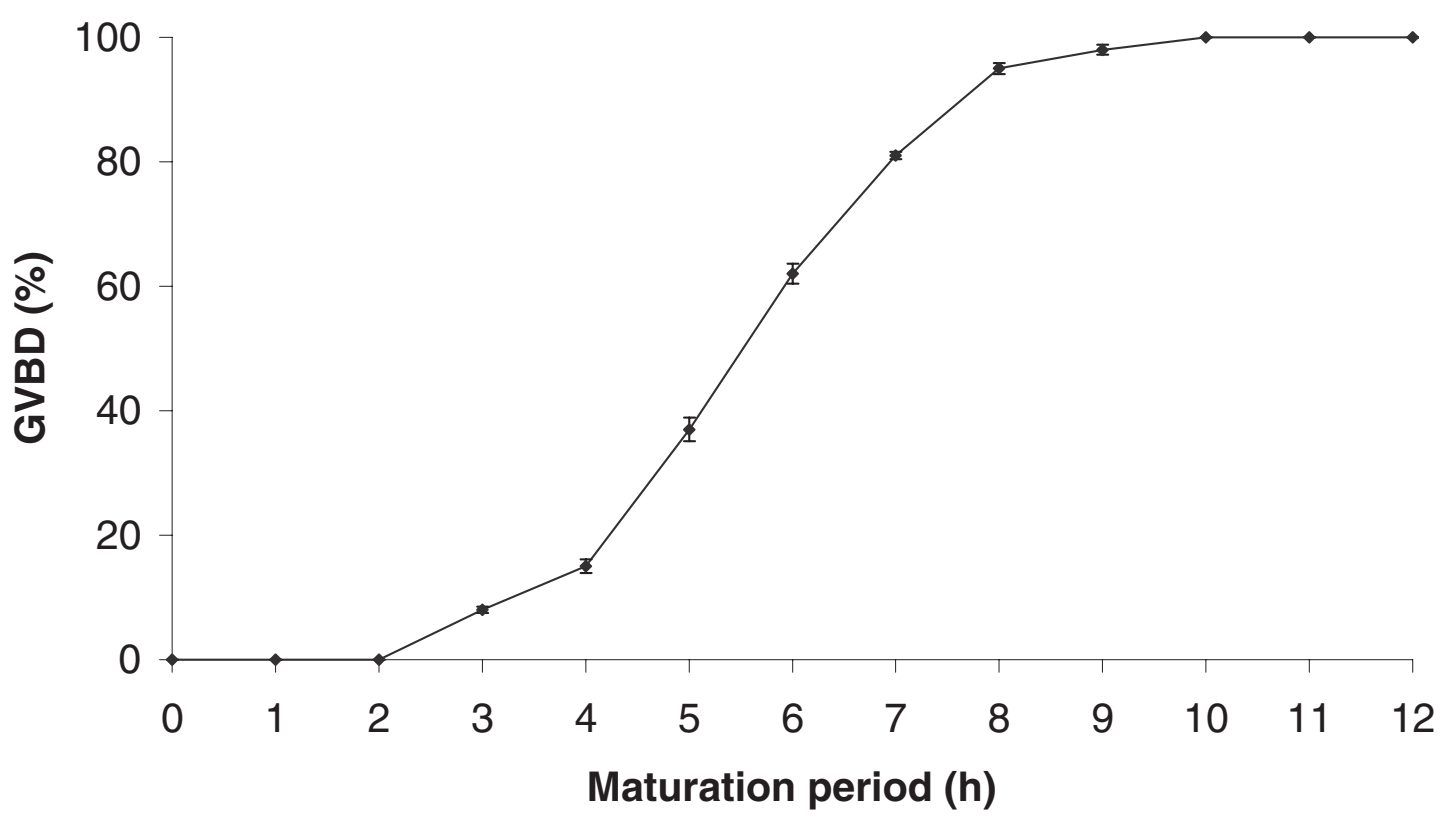

Figure 1 Time course of germinal vesicle breakdown (GVBD) of bovine oocytes following culture in vitro (total of 788 oocytes; three replicates).
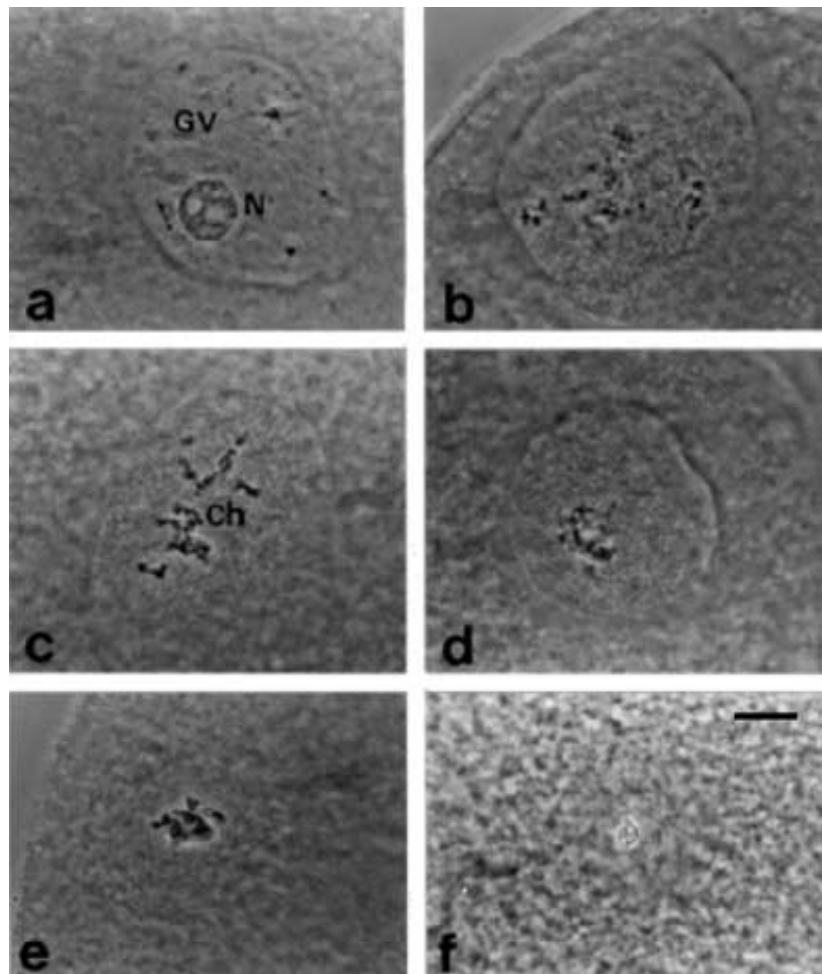

Figure 2 The process of germinal vesicle breakdown (GVBD) of bovine oocytes cultured in vitro. (a) Germinal vesicle (GV) in an oocyte after aspiration from its follicle. One clear nucleolus (N) is visible. (b) GV in an oocyte $1 \mathrm{~h}$ after culture; the nucleolus has already disappeared. (c) GV in an oocyte $2 \mathrm{~h}$ after culture; the chromosomes $(\mathrm{Ch})$ are beginning to gather. (d) GV in an oocyte $3 \mathrm{~h}$ after culture; chromosome condensation proceeds. (e) An oocyte $3 \mathrm{~h}$ after culture; GVBD has occurred. ( $f$ ) An oocyte $6 \mathrm{~h}$ after culture; the chromosomes are condensed. Scale bar represents $5 \mu \mathrm{m}$. oocyte GVBD (Fig. 6a-d). As shown in Fig. 7, the point of protein phosphorylation at approximately $18 \mathrm{kDa}$ increased following fertilisation. In contrast to Fig. 6, the point of protein phosphorylation at approximately 27 $\mathrm{kDa}$ is missing following fertilisation. However, the point of phosphoproteins at approximately $15 \mathrm{kDa}$ is absent during oocyte maturation in Fig. 6. Taking Figs. 5-7 together, there is indication that the point of protein phosphorylation at approximately $18 \mathrm{kDa}$ appears reversibly changed following oocyte maturation and fertilisation.

\section{Discussion}

The present study demonstrates that reversible changes in phosphoproteins occur during maturation and pronuclear formation in bovine oocytes. The morphological changes of GVBD in bovine oocytes observed in the present study are similar to those in previous reports (Motlik et al., 1978; Hyttel et al., 1986; De Loos et al., 1989). Although it has been reported that a visible nucleolus is not typically observed at the GV stage of bovine oocytes (Motlik et al., 1978), the results of the present study indicate that $12 \%$ of oocytes had clearly observed nucleoli within the GV after aspiration from the follicles (Fig. 2). It seems that the disappearance of nucleoli and the gathering of chromosomes are typical phenomena before GVBD, which were observed in most oocytes following $3 \mathrm{~h}$ of culture.

Protein phosphorylation plays a major role in the regulation of cell growth and division (Oelgeschläger, 


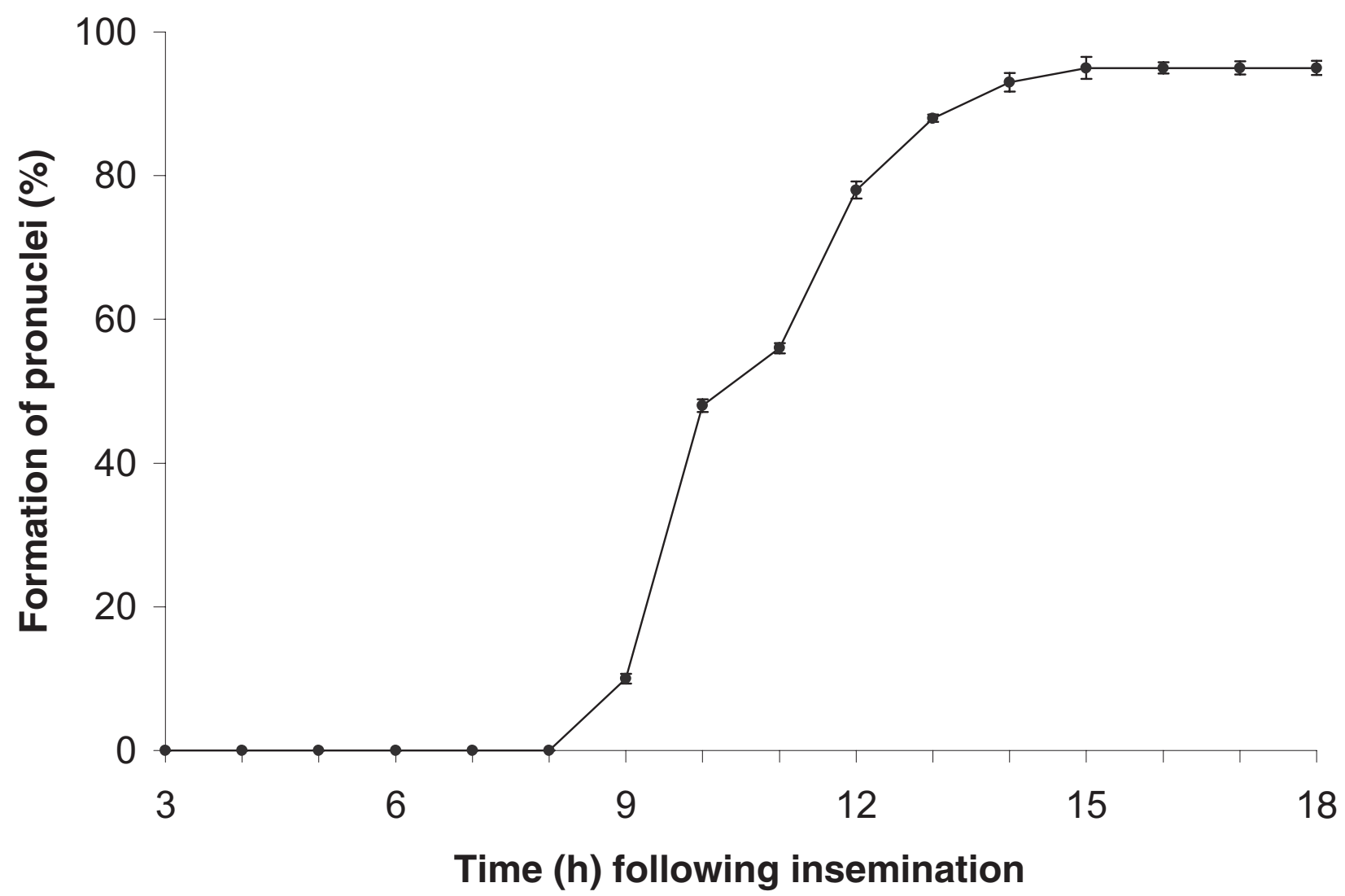

Figure 3 Time course of male and female pronucleus formation following in vitro fertilisation with frozen-thawed sperm (total of 724 oocytes; three replicates). Only oocytes penetrated by a single sperm were recorded.

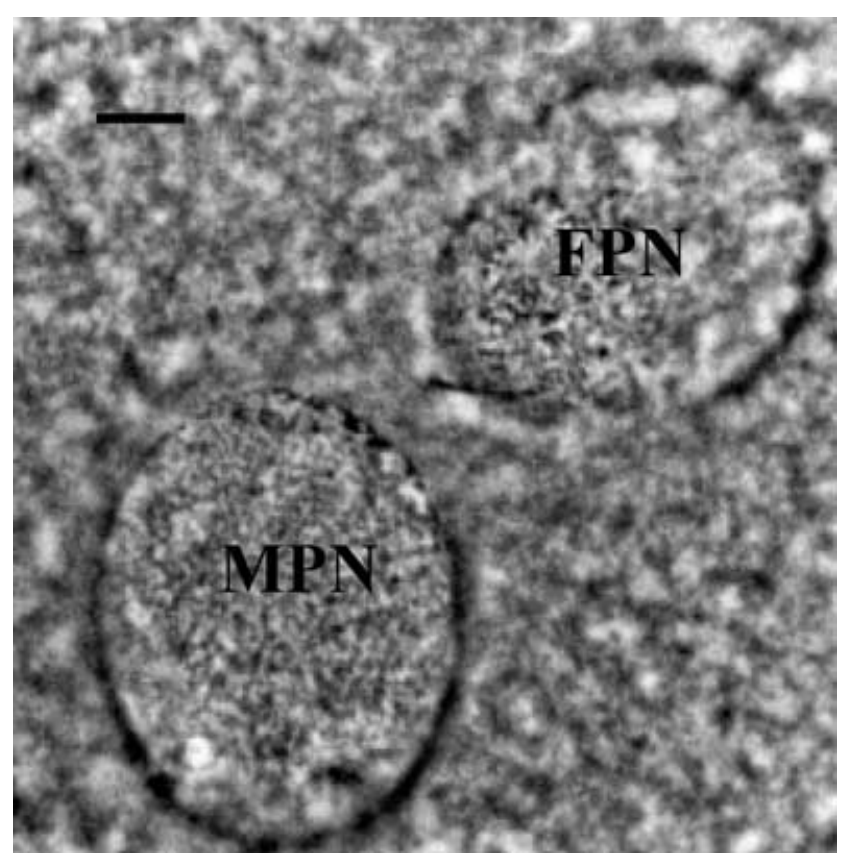

Figure 4 An oocyte fertilised $18 \mathrm{~h}$ after insemination showing male and female pronuclei (MPN, FPN) in the cytoplasm. Scale bar represents $5 \mu \mathrm{m}$.
2002). Results from studies with amphibian eggs indicate that protein phosphorylation plays an important role in controlling nuclear envelope assembly/breakdown and chromosome condensation/ decondensation in cell-free extracts (Lohka \& Maller, 1987). It has been reported that protein phosphorylation is increased at the time of GVBD in sheep oocytes (Crosby et al., 1984). Although it has been described that the specific changes in protein phosphorylation are programmed during bovine oocyte maturation, the exact function of these phosphoproteins during oocyte maturation is still largely unknown (Kastrop et al., 1990). The first GVBD was observed $3 \mathrm{~h}$ following incubation and it concurrently occurred from 3 to $10 \mathrm{~h}$ post-incubation (Fig. 1). Although less phosphorylation of proteins occurred during the oocytes in the first $3 \mathrm{~h}$ of culture, the levels of protein phosphorylation increased considerably $3 \mathrm{~h}$ after culture (Fig. 5a). The predominant increase in levels of protein phosphorylation at approximately $40 \mathrm{kDa}, 27 \mathrm{kDa}, 23 \mathrm{kDa}$ and $18 \mathrm{kDa}$ occurred from 3 to $6 \mathrm{~h}$ following maturation in culture. Apparently, the phosphorylation of these protein complexes accompanies oocyte GVBD.

During oocyte maturation, MPF directly regulates oocyte progression from the diplotene stage to 


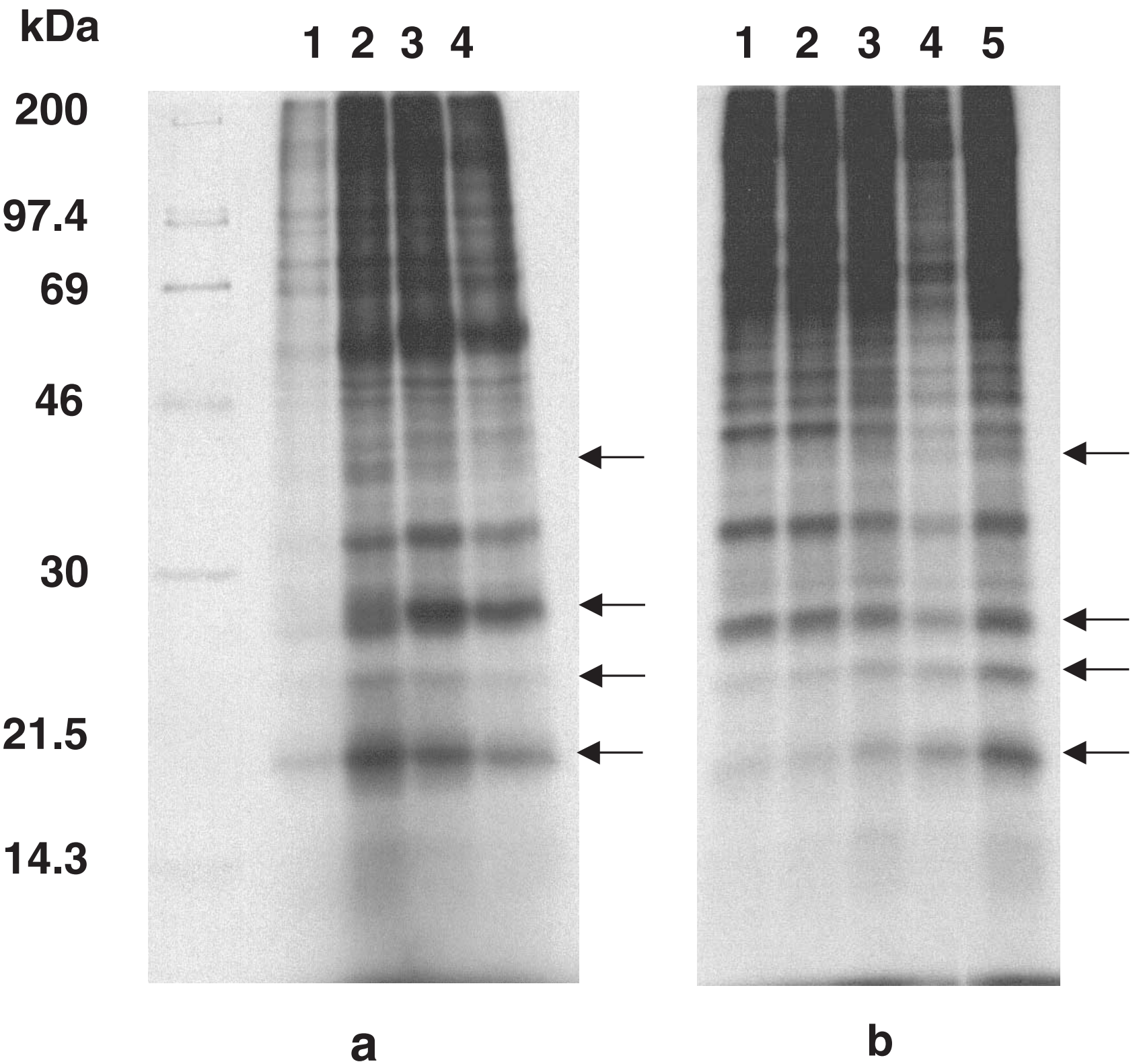

Figure 5 One-dimensional SDS-12\% polyacrylamide gel electrophoresis of [ $\left.{ }^{32} \mathrm{P}\right]$ orthophosphate-labelled proteins. Molecular weight (range $14300-200000$ ) is the migration of $\left[{ }^{14} \mathrm{C}\right]$ methylated proteins. (a) Incorporation of $\left[{ }^{32} \mathrm{P}\right]$ orthophosphate into phosphoproteins from 0 to 12 hours post-culture (hpc) for oocyte maturation. Lane 1, 0-3 hpc; lane 2, 3-6 hpc; lane 3, 6-9 hpc; lane 4, 9-12 hpc. (b) Protein phosphorylation of oocytes after fertilisation was labelled at $3 \mathrm{~h}$ intervals from 3 to 18 hours postinsemination (hpi). Lane 1, 3-6 hpi; lane 2, 6-9 hpi; lane 3, 9-12 hpi; lane 4, 12-15 hpi; lane 5, 15-18 hpi. Arrows point to the changes described in the text. Each lane represents 25 oocytes. The experiment was performed twice with similar results.

metaphase II. When MPF activity is first detected, an increase in protein phosphorylation occurs (Maller et al., 1977; Belle et al., 1978; 1979; Boyer et al., 1986). A tremendous increase in phosphoproteins occurs shortly before GVBD and in association with the activity of MPF in Xenopus oocytes, indicating that MPF is involved in oocyte GVBD (Maller \& Smith, 1985). Preparations of 3000-fold purified MPF contain two major components - a $34 \mathrm{kDa}$ protein and a $45 \mathrm{kDa}$ protein - and exhibit considerable kinase activity in vitro
Figure 6 Two-dimensional gel electrophoresis of [ $\left.{ }^{32} \mathrm{P}\right]$ orthophosphate-labelled proteins. Molecular weight (range 14 300-200 000) is the migration of $\left[{ }^{14} \mathrm{C}\right]$ methylated proteins. The phosphorylated proteins of the oocytes were first separated on IEF acryl gel with an ampholine range of 3-10, and secondly separated on $12 \%$ SDS-PAGE. The proteins phosphorylated in the oocytes were labeled at $3 \mathrm{~h}$ intervals from $0 \mathrm{~h}$ to $12 \mathrm{~h}$ following culture in vitro: (a) 0-6 hours post-culture (hpc); (b) 3-6 hpc; (c) 6-9 hpc; (d) 9-12 hpc. The arrows indicate the changes described in the text. Each lane represents 25 oocytes. The experiment was performed twice with similar results. 


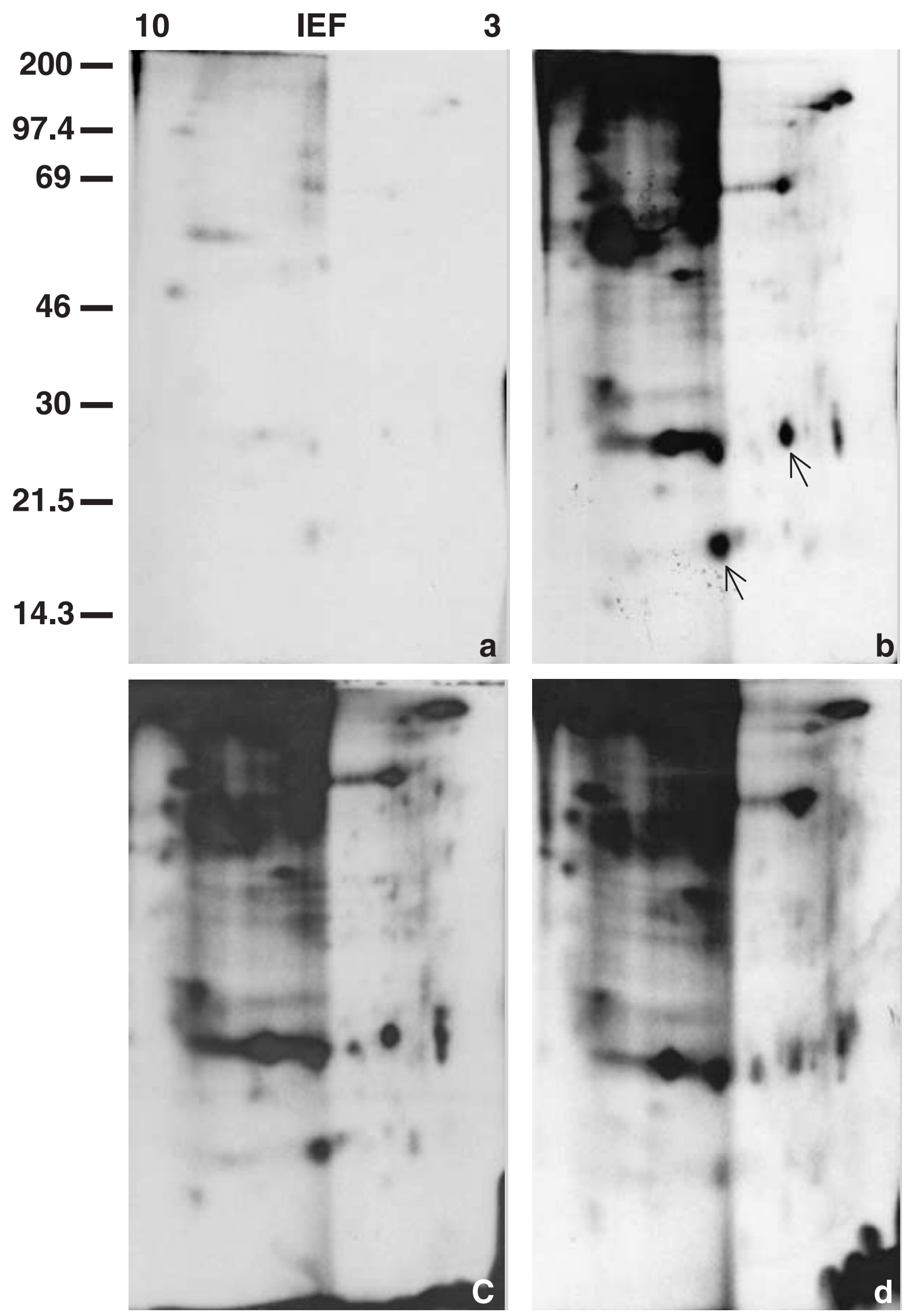



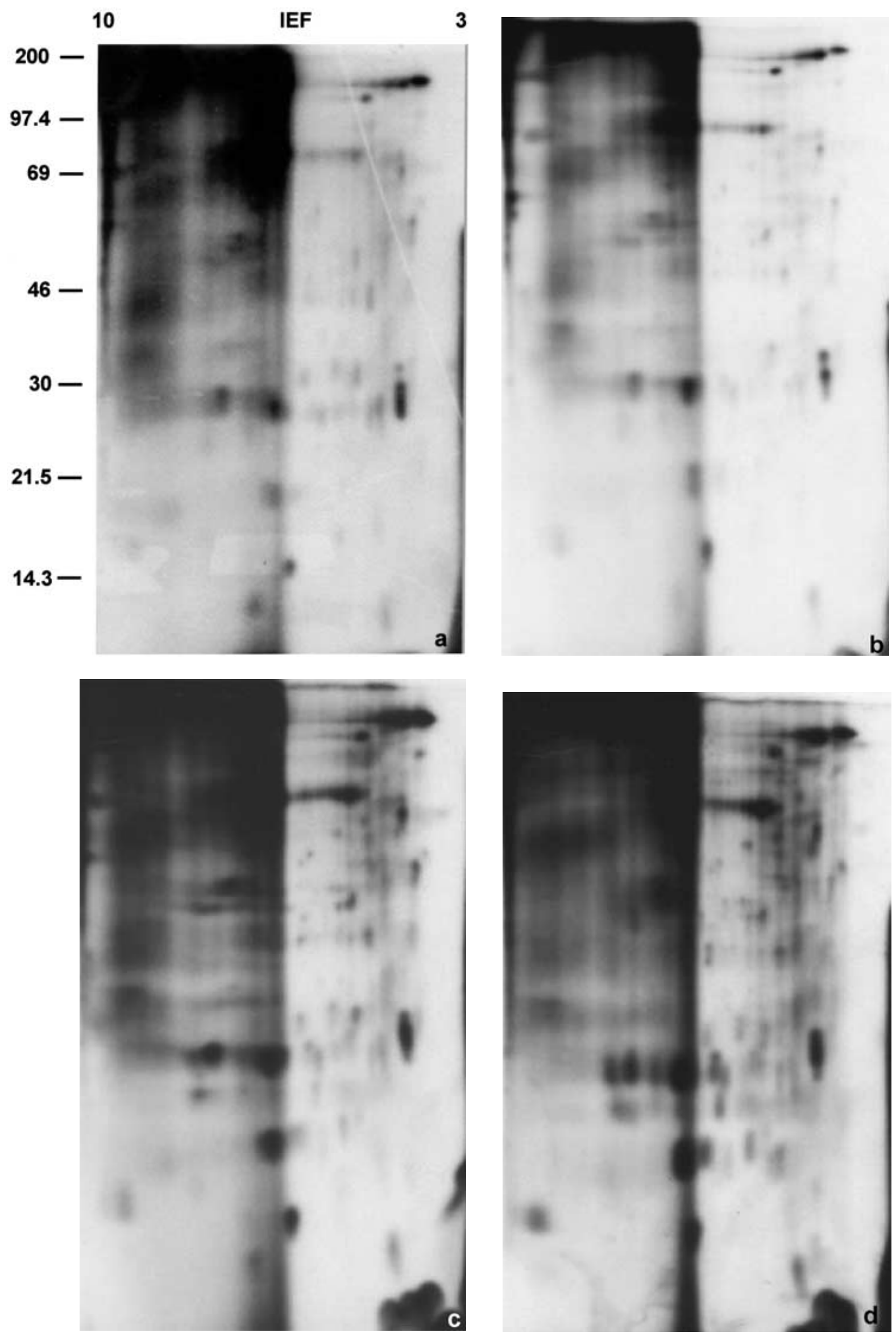


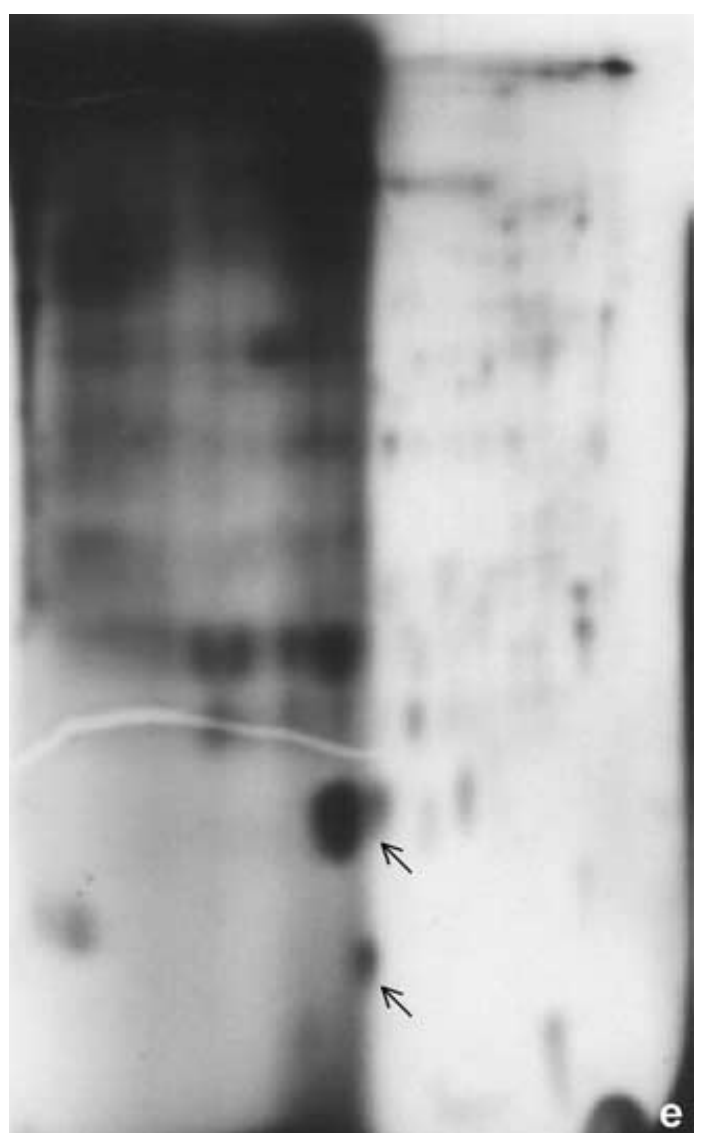

Figure 7 Two-dimensional gel electrophoresis of [32P]orthophosphate-labelled proteins. Molecular weight (range 14300-200 000) is migration of $\left[{ }^{14} \mathrm{C}\right]$ methylated proteins. The phosphorylated proteins of the oocytes were first separated on IEF acryl gel with an ampholine range of 3-10, and secondly separated on $12 \%$ SDS-PAGE. The proteins phosphorylated in the oocytes were labeled at $3 \mathrm{~h}$ intervals from 3 to $18 \mathrm{~h}$ following insemination in vitro: (a) 3-6 hours post-insemination (hpi); (b) 6-9 hpi; (c) 9-12 hpi; (d) 12-15 hpi; (e) 15-18 hpi. The arrows indicate the changes described in the text. Each lane represents 25 oocytes. The experiment was performed twice with similar results.

(Lohka et al., 1988). Activation of MPF requires key side phosphorylation and dephosphorylation. It is known that the product of the c-mos proto-oncogene, a protein serine/threonine kinase known as Mos (Sagata et al., 1989; Watanabe et al., 1989), and MAP kinase (Nebreda \& Hunter, 1993) directly or indirectly modify MPF activity with the status of phosphorylation or dephosphorylation. Therefore, the phosphorylated proteins at approximately $40 \mathrm{kDa}, 27 \mathrm{kDa}, 23 \mathrm{kDa}$ and $18 \mathrm{kDa}$ in the oocytes observed in the present study seem not to be MPF itself. Thus these phosphoproteins may play a role in the activation of MPF by putative substrates. These phosphoproteins could be unknown protein kinases or phosphatases, because there are a large number of protein kinase genes and protein phosphatase genes in oocytes. These phosphoproteins may play an important role in the meiotic cell cycle from G2 to M-phase. The role of the phosphorylation cascade of these proteins in the meiotic cell cycle needs to be further verified.

The sperm nucleus is transformed into the male pronucleus through the interaction of oocyte cytoplasmic components. At the time of pronucleus formation in mouse (Howlett \& Bolton, 1985; Howlett, 1986), porcine (Ding et al., 1992) and bovine (Chian et al., $1999 a$ ) oocytes, protein phosphorylation occurs. The first evidence of formation of male and female pronuclei was observed $9 \mathrm{~h}$ following insemination and observed concurrently from 10 to $18 \mathrm{~h}$ of post-insemination (Fig. 3). This finding is similar to our previous report (Chian et al., 1999b). Our previous results also indicate that the levels of protein phosphorylation at approximately $40 \mathrm{kDa}, 23 \mathrm{kDa}$ and $18 \mathrm{kDa}$ in bovine oocytes increase gradually following fertilisation and parthenogenetic activation and that there is a difference in the level of protein phosphorylation at $18 \mathrm{kDa}$ between fertilised and activated oocytes, suggesting that this phosphoprotein may be related to the formation of the male pronucleus in bovine oocytes (Chian et al., 1999b). Taken together the phosphoproteins results following oocyte maturation and fertilisation indicate that the point of protein phosphorylation at approximately $27 \mathrm{kDa}$ may be mainly related to oocyte GVBD. Interestingly, the point of protein phosphorylation at approximately $18 \mathrm{kDa}$ is reversibly changed during GVBD and following formation of pronuclei in bovine oocytes (Figs. 6, 7). This indicates that the reversible protein phosphorylation at approximately $18 \mathrm{kDa}$ in bovine oocytes may play an important role in the meiotic cell cycle from G2 to M-phase or pronucleus formation during oocyte maturation and fertilisation.

In conclusion, the results of the present study indicate that reversible changes in phosphoproteins occur during oocyte maturation and fertilisation, suggesting that this reversible change in phosphoproteins may play a key role in either the cell cycle transition or pronucleus formation during maturation and fertilisation in bovine oocytes.

\section{Acknowledgements}

The authors thank Dr Daniel Bousquet (L'Alliance Boviteq Inc.) and the Centre d'insemination artificielle du Quebec (CIAQ) Inc., and $\mathrm{Mr}$ Tom Kroetsch (GENCOR, Guelph, Ontario) for providing the frozen bovine semen. This research was supported by a grant from the Natural Sciences and Engineering Research Council (NSERC) of Canada (RGPIN 227107-00) to R.C.C. 


\section{References}

Balakier, H. \& Tarkowski, A. (1980). The role of the germinal vesicle karyoplasm in the development of the male pronucleus in the mouse. Exp. Cell Res. 128, 79-85.

Bavister, B.D., Leibfried, L.M. \& Lieberman, G. (1983). Development of preimplantation embryos of the golden hamster in a defined culture medium. Biol. Reprod. 28, 235-47.

Belle, R., Boyer, J. \& Ozon, R. (1978). Endogenous protein phosphorylation in Xenopus laevis oocytes: quantitative and qualitative changes during progesterone-induced maturation. Biol. Cell 32, 97-102.

Belle, R., Boyer, J. \& Ozon, R. (1979). Endogenous phosphorylated protein during maturation in Xenopus laevis oocytes. Gamete Res. 2, 137-45.

Boyer, J., Asselin, J., Belle, R. \& Ozon, R. (1986). Progesterone and cAMP-dependent protein kinase regulate in vivo the level of phosphorylation of two proteins (Mr 20000 and Mr 32 000) in Xenopus oocytes. Dev. Biol. 113, 420-8.

Chian, R.C. \& Sirard, M.A. (1996). Protein synthesis is not required for male pronuclear formation in bovine zygotes. Zygote 4, 41-8.

Chian, R.C., Niwa, K. \& Sirard, M.A. (1994). Effects of cumulus cells on male pronuclear formation and subsequence early development of bovine oocytes in vitro. Theriogenology 41, 1499-508.

Chian, R.C., Tan, S.L. \& Sirard, M.A. (1999a). Protein phosphorylation is essential for formation of male pronucleus in bovine oocytes. Mol. Reprod. Dev. 52, 43-9.

Chian, R.C., Tan, S.L. \& Sirard, M.A. (1999b). Protein phosphorylation in bovine oocytes following fertilization and parthenogenetic activation in vitro. Zygote 7, 135-42.

Crosby, I.M., Osborn, J.C. \& Moor, R.M. (1984). Changes in protein phosphorylation during the maturation of mammalian oocytes in vitro. J. Exp. Zool. 229, 459-66.

Dekel, N. (1996). Protein phosphorylation/dephosphorylation in the meiotic cell cycle of mammalian oocytes. Rev. Reprod. 1, 82-8.

De Loos, F.A.M., Van Vliet, C., Van Maurik, P. \& Kruip, T.A.M. (1989). Morphology of immature bovine oocytes. Gamete Res. 24, 197-204.

Ding, J., Clarke, N., Nagai, T. \& Moor, R.M. (1992). Protein and nuclear changes in pig eggs at fertilization. Mol. Reprod. Dev. 31, 287-96.

Gautier, J., Minshull, J. \& Lohka, M. (1990). Cyclin is a component of maturation promoting factor from Xenopus. Cell 54, 433-9.

Green, G.R. \& Piccia, D.L. (1985). Phosphorylation of sea urchin sperm $\mathrm{H} 1$ and $\mathrm{H} 2 \mathrm{~B}$ histones precedes chromatin decondensation and $\mathrm{H} 1$ exchanges during pronuclear formation. Dev. Biol. 108, 235-45.

Green, G.R. \& Piccia, D.L. (1989). Phosphorylation of sea urchin histone CS H2A. Dev. Biol. 134, 413-19.

Green, G.R., Collas, P., Burrell, A. \& Piccia, D.L. (1995). Histone phosphorylation during sea urchin development. Semin. Cell Biol. 6, 219-27.

Hagemann, L.J., Hillery-Weinhold, F.L., Leibfried-Rutledge, M.L. \& First, N.L. (1995). Activation of murine oocytes with $\mathrm{Ca}^{2+}$ ionophore cycloheximide. J. Exp. Zool. 271, 57-61.
Howlett, S.K. (1986). A set of proteins showing cell cycledependent modification in the early mouse embryo. Cell $45,387-96$.

Howlett, S. \& Bolton, V.N. (1985). Sequence and regulation of morphological and molecular events during the first cell cycle of mouse embryogenesis. J. Embryol. Exp. Morphol. 87, 175-206.

Hunter, T. (1995). Protein kinases and phosphatase: the yin and yang of protein phosphorylation and signaling. Cell 45, 225-36.

Hyttel, P., Xu, K.P., Smith, S. \& Greve, T. (1986). Ultrastructure of in vitro oocyte maturation in cattle. J. Reprod. Fertil. 78, 615-25.

Jung, T., Fulka, Jr J., Lee, C. \& Moor, R.M. (1993). Effects of the protein phosphorylation inhibitor genistein on maturation of pig oocytes in vitro. J. Reprod. Fertil. 98, 529-33.

Kastrop, P.M.M., Bevers, M.M., Destree, O.H.J. \& Kruip, T.A.M. (1990). Changes in protein synthesis and phosphorylation patterns during bovine oocyte maturation in vitro. J. Reprod. Fertil. 90, 305-10.

Kubelka, M., Rimkevicova, Z., Guerrier, P. \& Motlik, J. (1995). Inhibition of protein synthesis affects histone H1 kinase, but not chromosome condensation activity, during the first meiotic division of pig oocytes. Mol. Reprod. Dev. 41, 63-9.

Laemmli, U.K. (1970). Cleavage of structural proteins during the assembly of the head of bacteriophage T4. Nature 277, 680-5.

Lohka, M.J. \& Maller, J.L. (1987). Regulation of nuclear formation and breakdown in cell-free extracts of amphibian eggs. In Molecular Regulation of Nuclear Events in Mitosis and Meiosis (ed. R.A. Schlegel \& M.S. Halleck). New York: Academic Press, pp. 67-109.

Lohka, M.J., Hayes, M.K. \& Maller, J.L. (1988). Purification of maturation-promoting factor, an intracellular regulator of early mitotic events. Proc. Natl. Acad. Sci. USA 85, 3009-13.

Longo, F.J. \& Kunkle, M. (1978). Transformation of sperm nuclei upon insemination. Curr. Top. Dev. Biol. 12, 149-84.

Maller, J.L. \& Smith, D.S. (1985). Two-dimensional polyacrylamide gel analysis of changes in protein phosphorylation during maturation of Xenopus oocytes. Dev. Biol. 109, 150-6.

Maller, J.L., Wu, M. \& Gerhart, J.C. (1977). Changes in protein phosphorylation accompanying maturation of Xenopus laevis oocytes. Dev. Biol. 58, 295-312.

Moses, R.M. \& Kline, D. (1995). Release of mouse eggs from metaphase arrested by protein synthesis inhibition in the absence of a calcium signal or microtubule assembly. Mol. Reprod. Dev. 41, 264-73.

Moses, R.M. \& Masui, Y. (1994). Enhancement of mouse egg activation by the kinase inhibitor, 6-dimethylaminopurine (6-DMAP). J. Exp. Zool. 270, 211-18.

Motlik, J., Koefoed-Johsen, H.H. \& Fulka, J. (1978). Breakdown of the germinal vesicle in bovine oocytes cultivated in vitro. J. Exp. Zool. 205, 377-84.

Nebreda, A. \& Hunter, T. (1993). The c-mos proto-oncogene protein kinase turns on and maintains the activity of MAP kinase, but not MPF in cell free extracts of Xenopus oocytes and eggs. EMBO J. 12, 1979-83.

Norbury, C. \& Nurse, P. (1992). Animal cell cycles and their control. Annu. Rev. Biochem. 61, 441-70. 
Nurse, P. (1990). Universal control mechanism regulating onset of M-phase. Nature 344, 503-8.

Oelgeschläger, T. (2002). Regulation of RNA polymerase II activity by CTD phosphorylation and cell cycle control. J. Cell Physiol. 190, 160-9.

Parrish, J.J, Susko-Parrish, J.L., Leibfried-Rutledge, M.L., Critser, E.S., Eyestone, W.H. \& First, N.L. (1986). Bovine in vitro fertilization with frozen-thawed semen. Theriogenology 25, 591-600.

Parrish, J.J., Susko-Parrish, J.L., Weiner, M.A. \& First, N.L. (1988). Capacitation of bovine sperm by heparin. Biol. Reprod. 38, 11741-80.

Perreault, S.D., Wolff, R.A. \& Zirkin, B.R. (1984). The role of disulfide bond reduction during mammalian sperm nuclear decondensation in vivo. Dev. Biol. 101, 160-7.

Pines, J. \& Hunter, T. (1990). p34cdc2: the S and M kinase? New Biol. 2, 389-401.

Poccia, D. \& Collas, P. (1997). Nuclear envelope dynamics during male pronuclear development. Dev. Growth Differ. 39, 514-50.

Reyes, R., Carrnco, A., Huacuja, L. \& Delgado, N.M. (1991). Male pronuclei formation and release of phosphorylation of histone $\mathrm{H}-3$ during decondensation of human sperm nuclei activated in vitro by heparin. Arch. Androl. 26, 53-60. Sagata, N., Watanabe, N., Vande Woude, G.F. \& Ikawa, Y. (1989). The c-mos proto-oncogene product is a cytostatic factor responsible for mitotic arrest in vertebrate eggs. Nature 342, 512-18.

Thibault, C. (1977). Are follicular maturation and oocyte maturation independent processes? J. Reprod. Fertil. 51, $1-15$.

Watanabe, N., Vande Woude, G.F., Ikawa, Y. \& Sagata, N. (1989). Specific proteolysis of the c-mos oncogene by calpain on fertilization of Xenopus eggs. Nature 342, 505-11.

Wilson, R., Ainscough, R., Anderso, K., et al. (1994). 2.2 Mb of contiguous nucleotide sequence from chromosome III of $C$. elegans. Nature 368, 14-15.

Yanagimachi, R. (1978). Sperm-egg association in mammals. Curr. Top. Dev. Biol. 12, 83-105.

Zhang, S.C. \& Masui, Y. (1992). Activation of Xenopus laevis eggs in the absence of intracellular $\mathrm{Ca}^{2+}$ activity by the protein phosphorylation inhibitor, 6-dimethylaminopurine (6DMAP). J. Exp. Zool. 262, 317-29.

Zirkin, B.R., Soucek, D.A., Chang, T.S.K. \& Perreault, S.D. (1985). In vitro and in vivo studies of mammalian sperm nuclear decondensation. Gamete Res. 11, 349-65. 